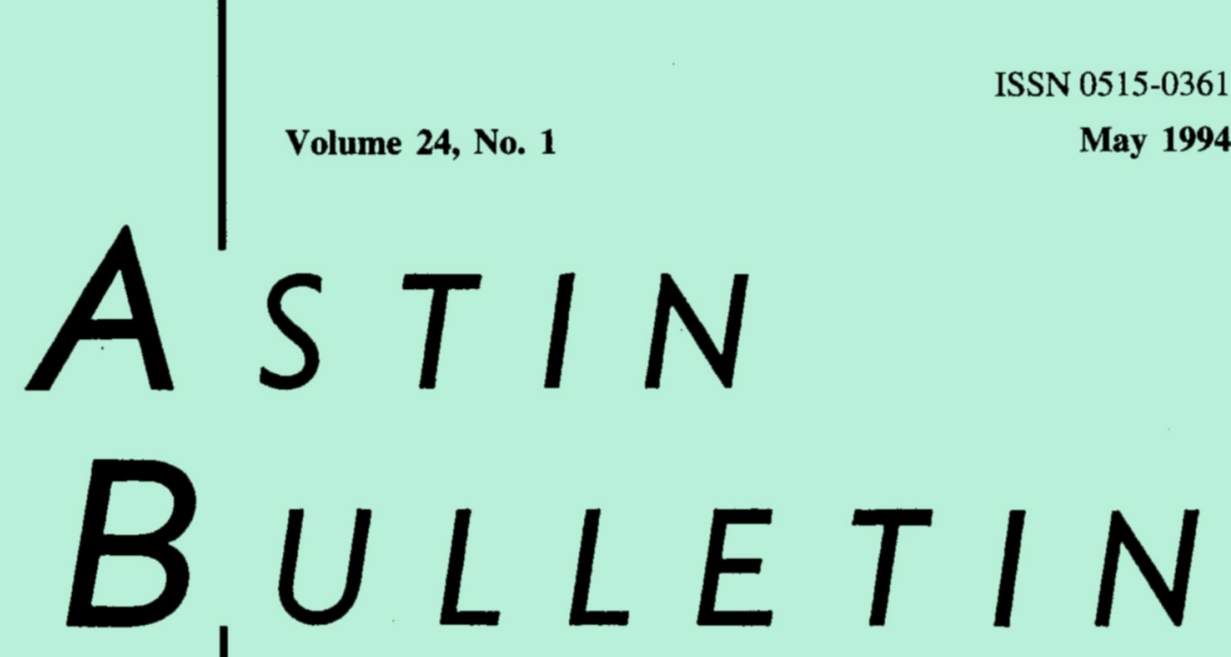

A Journal of the International Actuarial Association

EDITORS :

Hans Bühlmann Switzerland

D. Harry Reid United Kingdom

Co-Editors :

Alois Gisler Switzerland

David Wilkie United Kingdom

EDITORIAL BOARD :

Björn Ajne Sweden

Marc Goovaerts Belgium

Jacques Janssen Belgium

William S. Jewell USA

Jean Lemaire Belgium/USA

Walther Neuhaus Norway/Australia

Jukka Rantala Finland

Axel Reich Germany

James A. Tilley USA

\section{EDITORIAL AND ANNOUNCEMENTS}

Guest Editorial

\section{ARTICLES}

H. H. Müller, E. Chevallier

Risk Allocation in Capital Markets:

Portfolio Insurance, Tactical Asset Allocation and G.R.O.I. 5

O. Hesselager

A Recursive Procedure for Calculation of some Compound Distributions

D. C.M. DICKSON

Some Comments on the Compound Binomial Model

G. PARKER

Limiting Distribution of the Present Value of a Portfolio

\section{WORKSHOP}

J. Holtan

Bonus Made Easy

61

J. LEMAIRE, HoNGMin ZI

High Deductibles instead of Bonus-Malus: Can it Work?

K.-H. WALDMANN

On the Exact Calculation of the Aggregate Claims Distribution in the Individual Life Model

G. C. TAYLOR

Modelling Mortgage Insurance Claims Experience:

A Case Study

M. BosKov, R. J. VERRALL

Premium Rating by Geographic Area Using Spatial Models

\section{SHORT CONTRIBUTIONS}

H.U. GERBER

Martingales and Tail Probabilities

Actuarial Vacancy 


\section{EDITORIAL POLICY}

ASTIN BULLETIN started in 1958 as a journal providing an outlet for actuarial studies in non-life insurance. Since then a well-established non-life methodology has resulted, which is also applicable to other fields of insurance. For that reason ASTIN BULLETIN has always published papers written from any quantitative point of view - whether actuarial, econometric, engineering, mathematical, statistical, etc. - attacking theoretical and applied problems in any field faced with elements of insurance and risk. Since the foundation of the AFIR section of IAA, i.e. since 1988, ASTIN BULLETIN has opened its editorial policy to include any papers dealing with financial risk.

ASTIN BULLETIN appears twice a year (May and November), each issue consisting of at least 80 pages.

Details concerning submission of manuscripts are given on the inside back cover.

\section{MEMBERSHIP}

ASTIN and AFIR are sections of the International Actuarial Association (IAA). Membership is open automatically to all IAA members and under certain conditions to non-members also. Applications for membership can be made through the National Correspondent or, in the case of countries not represented by a national correspondent, through a member of the Committee of ASTIN.

Members of ASTIN receive ASTIN BULLETIN free of charge. As a service of ASTIN to the newly founded section AFIR of IAA, members of AFIR also receive ASTIN BULLETIN free of charge.

\section{SUBSCRIPTION AND BACK ISSUES}

ASTIN BULLETIN is published and printed for ASTIN by Ceuterick s.a., Brusselsestraat 153, B-3000 Leuven, Belgium.

All queries and communications concerning subscriptions, including claims and address changes, and concerning back issues should be sent to Ceuterick.

The current subscription or back issue price per volume of 2 issues including postage is BEF 2500.

Back issues up to issue 10 (= up to publication year 1979) are available for half of the current subscription price.

\section{INDEX TO VOLUMES 1-20}

The Cumulative Index to Volumes 1-20 is also published for ASTIN by Ceuterick at the above address and is available for the price of BEF 400 . 